Рекомендована д. фрармац. наук, профр. В. В. Трохимчуком

УДК 615.244:339.13

\title{
ДОСЛІДЖЕННЯ СТРУКТУРИ УКРАЇНСЬКОГО РИНКУ ЛІКАРСЬКИХ ЗАСОБІВ ДЛЯ ЛІКУВАННЯ ЗАХВОРЮВАНЬ ГЕПАТОБІЛІАРНОЇ СИСТЕМИ
}

\author{
(СА. В. Волкова, А. І. Федосов, В. С. Кисличенко \\ Національний фрармацевтичний університет, Харків
}

\begin{abstract}
Резюме: проведено аналіз українського ринку лікарських засобів для лікування захворювань гепатобіліарної системи та встановлено його основні особливості. За результатами дослідження визначено, що загальна чисельність препаратів становить 113 найменувань, які поставляють 319 країн-виробників. Проведено структурний аналіз підгруп лікарських засобів за АТС-класифікацією II рівня і встановлено кількість найменувань препаратів та представленість різними лікарськими фрормами у кожній підгрупі.
\end{abstract}

Ключові слова: захворювання печінки та жовчовивідних шляхів, ринок лікарських засобів, маркетинговий аналіз.

Вступ. У сучасній гастроентерології значна увага приділяється питанням лікування захворювань печінки та жовчовивідних шляхів, оскільки за поширеністю та хронічним характером вони поступаються лише патології серцево-судинної системи [1-3]. Так, за даними Всесвітньої організації охорони здоров'я, від хронічних захворювань печінки страждають близько 29 млн мешканців європейських країн [4]. Сукупність фракторів впливу навколишнього середовища, особливості способу життя сучасної людини, токсичність лікарських засобів (ЛЗ), які застосовують при терапії чисельних хвороб, фрормують не повний перелік пускових фракторів розвитку хвороб печінки та жовчовивідних шляхів. Патогенез даної патології, в свою чергу, призводить до розвитку деструктивних процесів і зумовлює хронічний перебіг $[1,5]$. За таких умов актуальним $є$ питання ефективного, своєчасного, нетоксичного і доступного лікування для хворого.

Метою нашого дослідження стало вивчення ринку ЛЗ для лікування захворювань печінки та жовчовивідних шляхів та визначення особливостей його структури.

Методи дослідження. У роботі використано дані Державного реєстру Л3, дослідницьких компаній і виробничих підприємств, які узагальнено за допомогою методів маркетингового, структурного, статистичного та графрічного аналізів.

Результати й обговорення. За результатами госпітальних закупівель у 2014 р. у розрізі груп I рівня АТСкласифрікації препарати групи А «Засоби, які впливають на травну систему і метаболізм» у загальному обсязі реалізованих Л3 займають 19,2 \% у грошовому виразі та 11,4 \% у натуральному, і знаходяться на другому місці серед усіх фрармакологічних груп [6]. Поведений нами аналіз ринкових обсягів реалізації у підгрупах даного сегмента ЛЗ свідчить про переважну кількість препаратів групи А07 «Антидіарейні засоби; засоби, які застосовуються при інфекційно-запальних захворювань кишківника» (майже 20,3 \% сегменту). Препарати групи А05 «Засоби для лікування захворювань печінки та жовчовивідних шляхів» складають 6,39 \% сегмента від загальної ємності (рис. 1).

Наступним етапом нашого дослідження стало проведення аналізу сегмента ЛЗ для лікування гепатобіліарної патології, який включає наступні підгрупи:

А05А Засоби, що застосовуються при біліарній патології:

А05А А02 Кислота урсодезоксихолева;

А05А X10** Різні препарати, включно комбінації;

А05В Засоби, що застосовуються при захворюваннях печінки, ліпотропні речовини:

А05B А01 Аргініну глутамат;

А05B А03 Силімарин;

А05В А06 Орнітину оксоглурат;

А05B A50** Різні препарати;

A05B A53** Силімарин, комбінації.

За результатами аналізу співвідношення виробників у даному сегменті встановлено переважну представленість ЛЗ вітчизняного виробництва у групі А05А та закордонного у групі А05В (рис. 2).

Слід відзначити, що серед 7 підгруп аналізованого сегмента найбільшими $є$ групи A05A X10** та A05B A50**, кількість Л3 у яких за торговельними назвами з урахування лікарських фрорм та без урахування дозувань становить 37 та 34 відповідно. До того ж, переважна кількість препаратів (25 найменувань) у групі A05A X10*夫 вітчизняного виробництва.

Також нами проаналізовано представленість різних країн-виробників ЛЗ для лікування захворювань печінки та жовчовивідних шляхів (рис. 3). Встановлено, що на український ринок ЛЗ даної групи поставляються 34 виробниками 318 країн. Сегмент українського виробництва представлений Л3 26 виробників загальною чисельністю 55 препаратів.

ISSN 2312-0967. Фармацевтичний часопис. 2015. № 2 
Фармацевтичний менеджмент, маркетинг та логістика

Pharmaceutical management, marketing and logistics

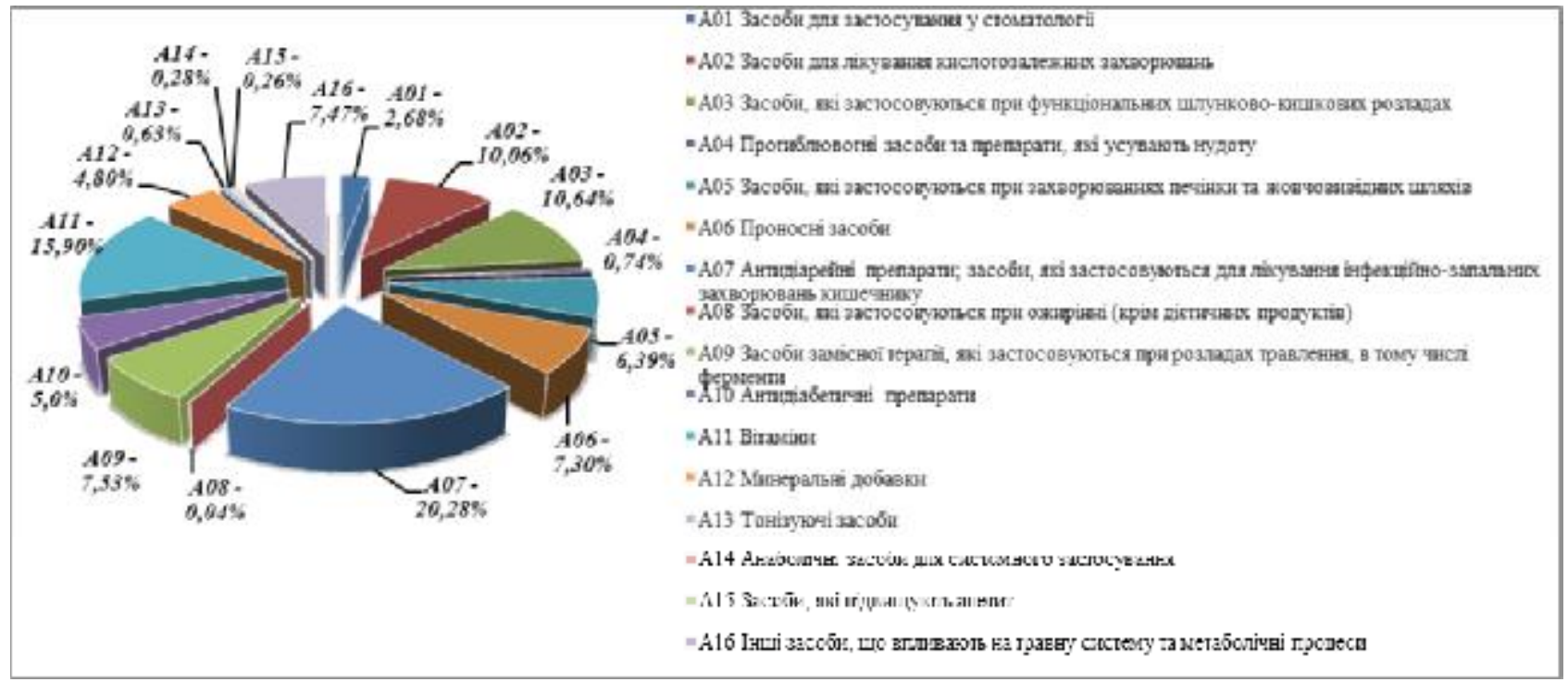

Рис. 1. Структура сегмента ЛЗ, які впливають на травну систему і метаболізм.
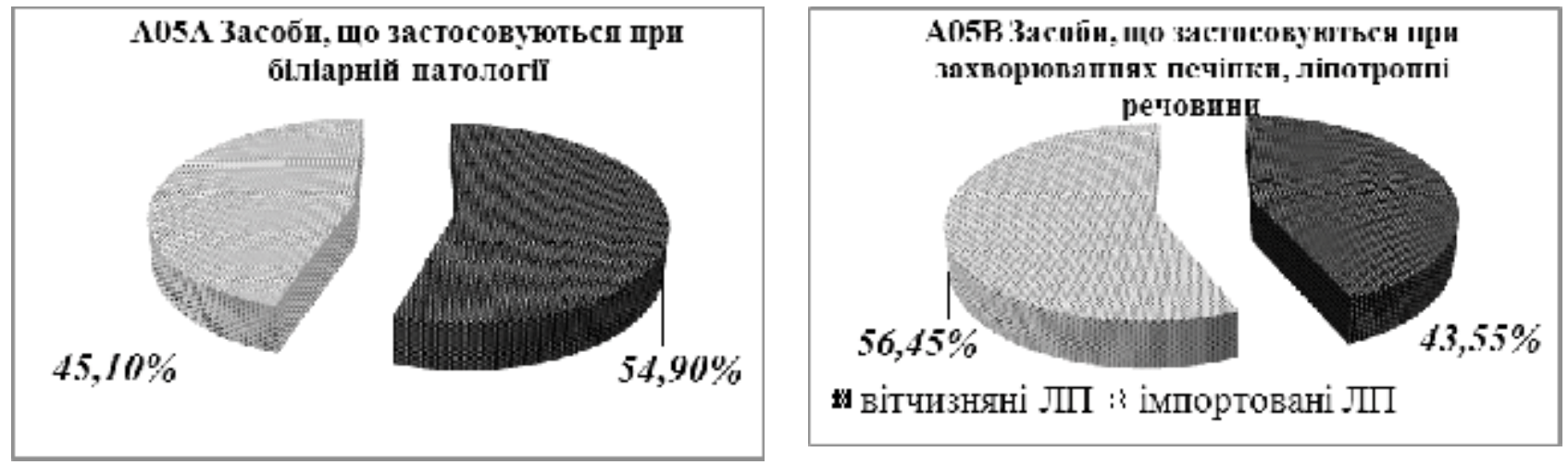

Рис. 2. Співвідношення вітчизняних та імпортованих лП на ринку України.

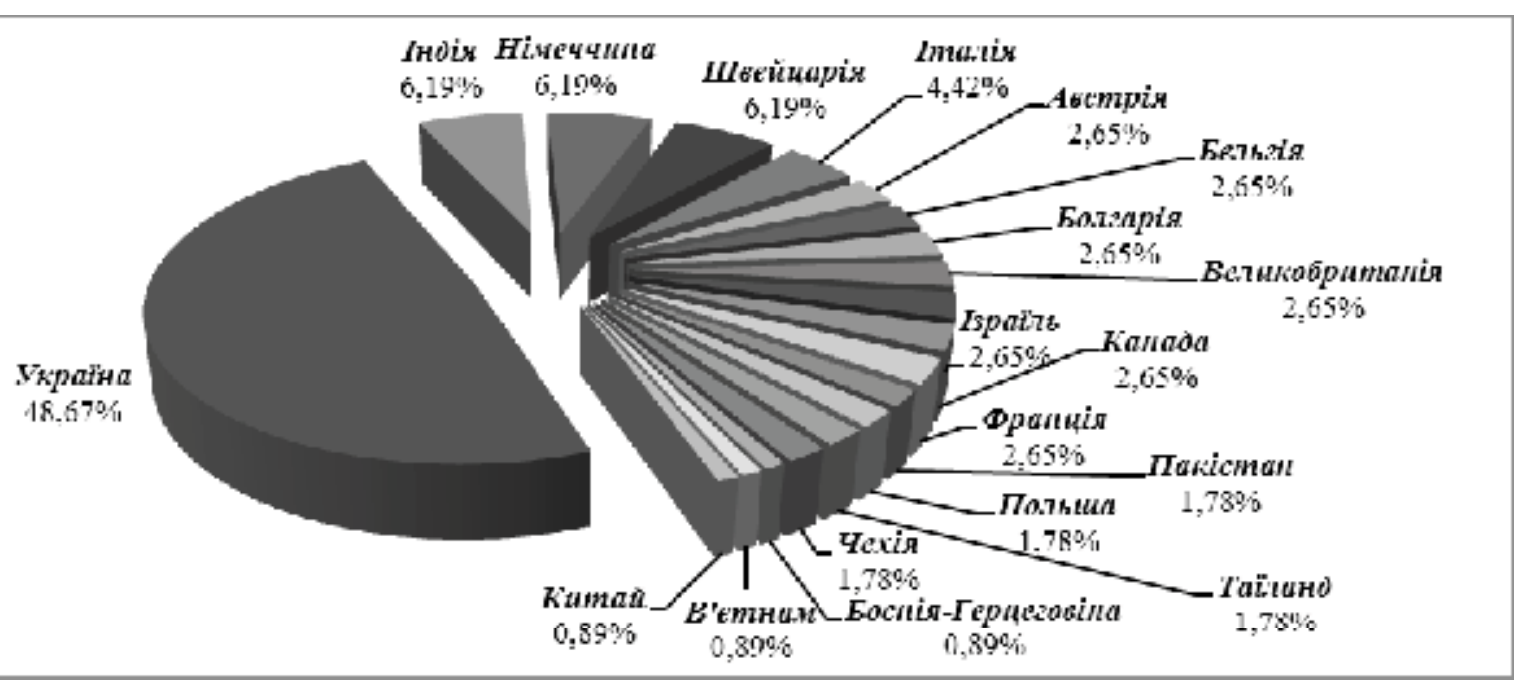

Рис. 3. Розподіл країн-виробників ЛЗ для лікування захворювань печінки та жовчовивідних шляхів.

ISSN 2312-0967. Pharmaceutical review. 2015. № 2 
Фармацевтичний менеджмент, маркетинг та логістика Pharmaceutical management, marketing and logistics

Наступний етап нашого дослідження передбачав проведення структурного аналізу представленості різних лікарських фрорм у сегментах аналізованого ринку Л3, за результатами якого встановлено, що препарати для лікування гепатобіліарної патології виробляються у 14 лікарських фрормах. Найбільша кількість Л3 представлена на ринку у фрормі капсул
(53 найменування) і таблеток (46 найменувань), найменш чисельними $є$ гранули, концентрати для приготування розчинів для інфузій та рідкі лікарські форми (суспензія оральна, розчин перооральний), які представлені по 3 найменуванням ЛЗ. Загальний розподіл лікарських форм серед підгруп сегмента, що аналізується, наведено на рисунку 4.

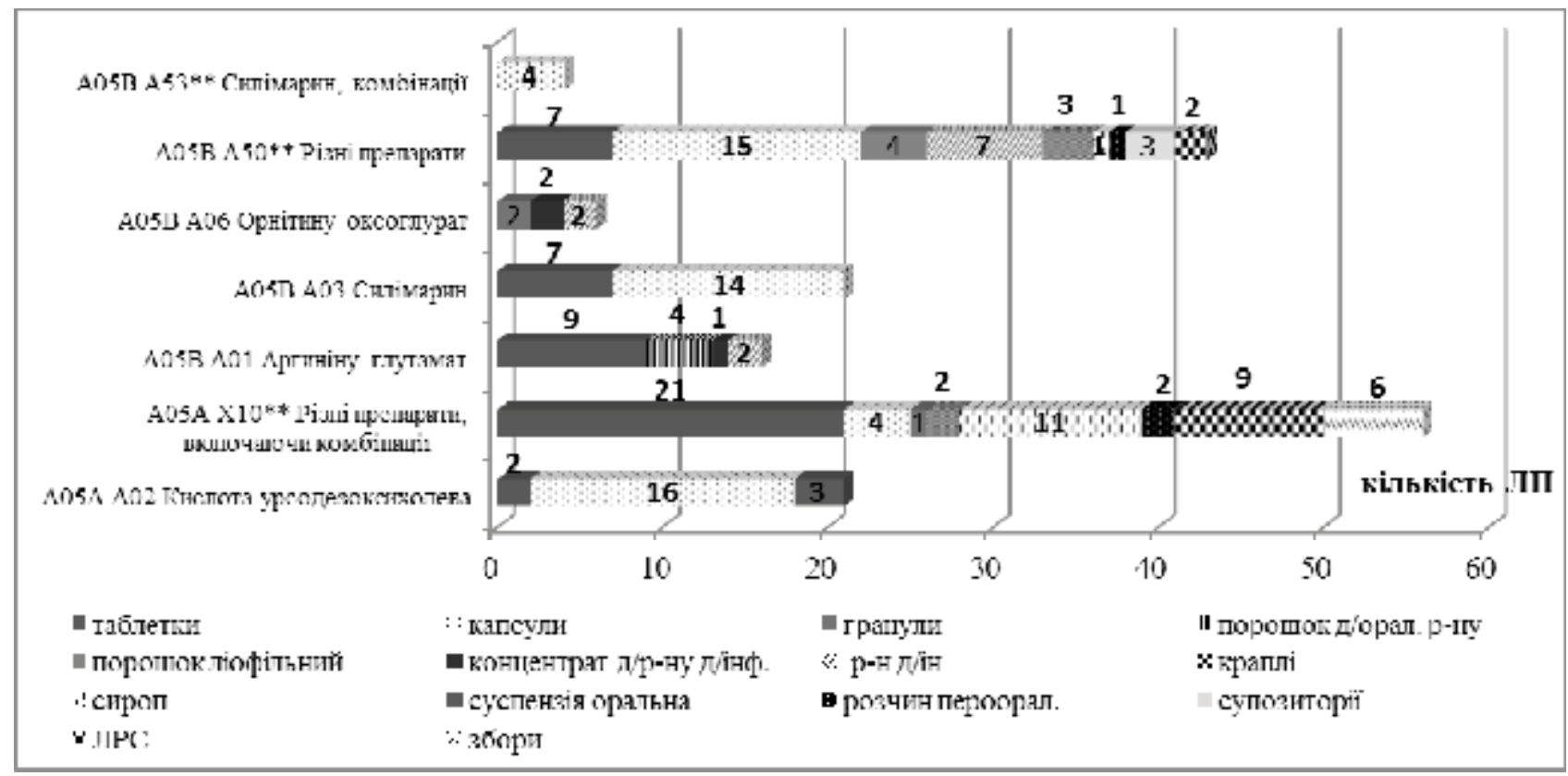

Рис. 4. Розподіл Лз для лікування захворювань печінки та жовчовивідних шляхів за формами випуску.

Висновки. Таким чином, можна стверджувати, що український ринок ЛЗ для лікування гепатобіліарної патології характеризується широким асортиментом і представлений 7 групами II рівня АТС-класифікації.

Встановлено, що препарати поставляються від 60 виробників з 19 країн і майже рівномірно представлені українськими та закордонними підприємствами. Структурний аналіз підгруп ЛЗ для лікування захво- рювань печінки та жовчовивідних шляхів свідчить про переважну кількість лікарських фрорм і чисельності найменувань у сегментах комбінованих засобів.

Слід вказати, що фрормування сегментів препаратів і тенденція їх розвитку залежить від чисельності факторів ринкового середовища прямого і опосередкованого впливу, які вважаємо за доцільне розглянути у подальших дослідженнях.

\section{Література}

1. Некоторые аспекты применения препаратов урсодезоксихолевой кислоты в сочетании с экстрактами растений в лечении заболеваний гепатобилиарной системы / Г. А. Анохина, В. В. Харченко, Н. Д. Опанасюк [и др.] // Сучасна гастроентерологія. - 2014. - № 1 (75). - C. 49-54.

2. Шипулин В. П. Внешнесекреторная недостаточность поджелудочной железы при хронических дифрфузных заболеваниях печени / В.П.Шипулин, В.В.Чернявский // Сучасна гастроентерологія. - 2012. - № 2 (64). C. 122-127.

3. Hepatobiliary cystadenoma of the liver prolapsing into the extrahepatic bile duct / Y. Abe, K. Kasuya, T. Itoi [et al.] // Gastrointestinal Endoscopy. - 2012. - Vol. 75 (5). P. 1099-1100.

4. Бабак О. Я. Современная гепатология: достижения, проблемы и перспективы / О. Я. Бабак // Сучасна гастроентерологія. - 2013. - № 2 (70). - С. 12-20.

5. Gundermann K. J. Activity of essential phospholipids (EPL) form soybean in liver disease / K. J. Gundermann, A. Kuenker // Pharmacological Report. - 2011. - Vol. 63. - P. 643-659.

6. Кирсанов Д. Госпитальные закупки в Украине по итогам 2014 г. Helicopter view / Д. Кирсанов // Щотижневик «Аптека». - 2014. - № 9 (980). - [Електронний ресурс]. Режим доступу : http://www.apteka.ua/article/326079.

ISSN 2312-0967. Фармацевтичний часопис. 2015. № 2 


\title{
ИССЛЕДОВАНИЕ СТРУКТУРЫ УКРАИНСКОГО РЫНКА ЛЕКАРСТВЕННЫХ СРЕДСТВ ДЛЯ
} ЛЕЧЕНИЯ ЗАБОЛЕВАНИЙ ГЕПАТОБИЛИАРНОЙ СИСТЕМЫ

\author{
А. В. Волкова, А. И. Федосов, В. С. Кисличенко \\ Национальный фрармацевтический университет, Харьков
}

Резюме: проведен анализ украинского рынка лекарственных средств для лечения заболеваний гепатобилиарной системы и установлены его основные особенности. По результатам исследования определено, что общая численность препаратов составляет 113 наименований, которые поставляются из 19 стран-производителей. Проведен структурный анализ подгрупп лекарственных средств в соответствии с АТС-классификацией II уровня и установлено количество наименований препаратов и представленность различными лекарственными формами в каждой подгруппе.

Ключевые слова: заболевания печени и желчевыводящих путей, рынок лекарственных средств, маркетинговый анализ.

\section{THE RESEARCH OF UKRAINIAN MEDICINES MARKET STRUCTURE FOR THE TREATMENT OF HEPATOBILIARY SYSTEM DISEASES}

\section{A. V. Volkova, A. I. Fedosov, V. S. Kyslychenko}

National University of Pharmacy, Kharkiv

Summary: the analysis of the Ukrainian medicines market for treatment of hepatobiliary system diseases is carried out and its main features are established. By results of research it is defined that the total number of preparations makes 113 names which are delivered from 19 manufacturing countries. The structural analysis of medicines subgroups according to ATC-classification of the II level is carried out and the number of names of preparations and representation by various dosage forms in each subgroup is established.

Key words: diseases of the liver and biliary tract, the market of medicines, marketing analysis. 